\title{
The geographies of collective action,
}

\section{principal-agent theory and potential}

\section{corruption in Papua New Guinea}

\section{Grant W Walton and Ainsley Jones}

\section{Abstract}

Recent theorizing on corruption is split between two approaches: corruption is described as a collective action or principal-agent problem. Insights from political science and geography suggest that these theories are not as bifurcated as some of the literature indicates, as their explanatory power is shaped by place-specific factors. This article draws on observations of administrative and community responses to decentralization policy in Papua New Guinea. Despite efforts of policy makers to institutionalize principal-agent theory inspired systems of government, we argue that state-society relations have meant that the potential for corruption is a part of a collective action problem in some places and a principal-agent problem in others. The applicability of these theories is determined by the degree of alignment between cultural and social values and administrative norms, which have been shaped by historic, political and economic factors. We call for a more nuanced understanding - one that better accounts for spatial difference - of the applicability of these theories beyond the scale of the nation-state.

\section{Development Policy Centre Discussion Paper 58}




\section{The geographies of collective action, principal-agent theory and potential corruption in Papua New Guinea}

\section{Grant W Walton ${ }^{1}$ and Ainsley Jones ${ }^{2}$}

Grant Walton is a Research Fellow at the Development Policy Centre, Crawford School of Public Policy, Australian National University.

Ainsley Jones was as a Research Officer at the Development Policy Centre.

Walton, G \& Jones, A 2017- "The geographies of collective action, principalagent theory and potential corruption in Papua New Guinea," Development Policy Centre Discussion Paper \#58, Crawford School of Public Policy, The Australian National University, Canberra.

The Development Policy Centre is a research unit at Crawford School of Public Policy, The Australian National University. The discussion paper series is intended to facilitate academic and policy discussion. Use and dissemination of this discussion paper is encouraged; however, reproduced copies may not be used for commercial purposes.

The views expressed in discussion papers are those of the authors and should not be attributed to any organisation with which the authors might be affiliated.

For more information on the Development Policy Centre, visit

http://devpolicy.anu.edu.au/

\footnotetext{
${ }^{1}$ Corresponding author and presenter, contact: grant.walton@anu.edu.au

${ }^{2}$ Ainsley recently completed her honours in Development Studies, entitled "Missing in Action: The Diminished Role of Collective Action in Responses to Corruption in Papua New Guinea".
} 


\section{The geographies of collective action, principal-agent theory and potential corruption in Papua New Guinea}

\section{Introduction}

In trying to understand the lack of progress made in effectively combating corruption in developing countries, academics (Persson, Rothstein, \& Teorell, 2013; Peiffer \& Alvarez, 2014; Peiffer \& Marquette, 2015) and development agencies have turned to theories of collective action. The collective action theory turn moves away from principal-agent theory inspired explanations of corruption, which focus on the asymmetries of power and information between principals and agents, to focus on the incentives for groups to condone or resist corrupt behavior. The critique of how principal-agent theory has been applied to corruption has arisen within economics and some strands of political science. Collective action theory is increasingly considered relevant for unravelling the complexities of corruption, particularly in societies where the Weberian state is weak.

The embryonic literature on collective action and corruption tends to bifurcate between collective action and principal-agent explanations; a view that is currently being challenged (Peiffer \& Marquette, 2015). Rather than being seen as two opposing theories, Peiffer and Marquette (2015) have suggested that the efficacy of these approaches is determined by context. In some contexts, principal-agent theory explains corruption better than collective action theory. Intuitively this makes sense, but there are still questions about what factors might best explain the potential for corruption in one context over another, and what this means for addressing corruption. Insights from principal-agent theory have long influenced anti-corruption responses and the everexpanding literature on corruption. Much less has been written about how to move corruption from a collective action problem to a solution, particularly below the scale of the nation-state. This diminishes our understanding of the potential for collective action theory inspired solutions to emerge from contexts where principal-agent theory fails to explain and adequately respond (that is, come up with policy solutions) to potential and actual corruption. This is particularly the case in the political science and economics literature, which has a tendency to preference a national-focused methodology over research within nation-states (see: Mungiu-Pippidi et al., 2011; Rothstein, 2011; Persson et al., 2013). The danger with focusing on the national scale is that entire countries can 
be deemed to be systematically corrupt. In turn, solutions to the problem can seem more remote than they might otherwise be.

This article draws on observations of administrative and community responses to decentralization policy in Papua New Guinea - a country famous for its internal diversity, which can challenge homogenizing generalisations. It shows that the relevance of principal-agent and collective action theories are shaped by historical, political, administrative, cultural and social factors that are place-specific. Moreover, it highlights how collective action solutions are drawn upon by those both marginalized and enfranchised by state-sponsored development. In turn, it highlights how the potential for collective action solutions to corruption vary in unexpected ways. The paper first provides an overview of recent debates about principal-agent theory and collective action theory. The second section provides a background on the case for this study - Papua New Guinea. The third provides a brief overview of the methodology. Research findings are discussed in section four. The article concludes by highlighting the importance of understanding the nature of corruption through a comparative approach that accounts for differences within countries, as well as between them.

\section{Moving from principal-agent to a collective action theory of corruption}

To date, international anti-corruption literature and policy has been predominantly influenced by principal-agent theory (Ugur \& Dasgupta, 2011; Sööt \& Rootalu, 2012), a theory that gained prominence in the 1970s among economists before being adopted by political scientists and sociologists (Miller, 2005). The principal-agent theory of corruption is based around two key actors: the principal (variously depicted as government ministers, agencies, or voters) and the agent, groups or individuals that the principal monitors. This theory has been adopted by those writing about corruption who argue that corruption occurs when information and preference asymmetry between principals and agents provides incentive for agents to engage in corruption. In other words, corruption occurs when principals are unable to adequately monitor agents and when the goals of the two are not aligned. For example, a politician (agent) might engage in corruption because they are inadequately monitored by citizens (principals). In turn, principal-agent theories on corruption call for measures - such as 
greater transparency and accountability of agents - that enable the principal to monitor and sanction the agent, and incentives to align the goals of both agents and principals. This approach has become central to the international anti-corruption agenda (Ugur \& Dasgupta, 2011) in organisations such as the World Bank, the International Monetary Fund (IMF) and the United Nations (Bukovansky, 2006; Harrison, 2006) and in most, if not all, bilateral aid programs.

There has been a growing sense among some scholars and anti-corruption actors that principal-agent responses to corruption have been wholly inadequate for addressing corruption (Johnsøn, Taxell, \& Zaum, 2012; Persson et al., 2013). This is particularly the case in developing countries where the Weberian state is weak and communal societies are strong. For example, Persson and colleagues (2013) draw on findings from Kenya and Uganda to argue that corruption has become a norm. In response, there has been a turn to collective action theoretical literature to reframe debates about the causes and possible solutions to corruption.

Drawing on the seminal work of Olson (1965), broader collective action theory challenges the common assumption that rational individual self-interest correlates to the common good (Barr, Packard, \& Serra, 2012). For Ostrom (1998) this is because individuals can 'free-ride' and benefit from non-excludable collective goods without necessarily contributing to them, as public goods can be enjoyed by all. While acknowledging the importance of monitoring and incentives, collective action proponents stress that systemic corruption emerges from group dynamics, particularly a lack of group trust. This forces a collective action problem of the 'second order', where shirking is perpetuated because no individual can trust that others will not free ride at the group's expense (Ostrom, 2007).

This theory has been applied to the study of corruption, with scholars arguing that in societies with systematic corruption, individuals have few incentives not to engage in corrupt behaviour. For some (e.g. Persson et al., 2013), the free rider problem leads to citizens accepting and/or actively participating in corruption even though they may understand that it is ultimately harmful to society. This leads to particularistic forms of governance problems through practices that dissolve the principal-agent distinction. For example, the "adverse selection" (appointing dishonest individuals into public office 
[see You, 2015: 24]) of agents by principals, undermines the ability of principals to properly monitor agents (You, 2015; Aspinall, 2016). Adverse selection of politicians by voters, or bureaucrats by politicians, strengthens patronage networks and can lead to corruption (You, 2015; Aspinall, 2016). Such activities prevent the movement from 'particularist' - distributing good to specific groups - to 'universalist' (also known as 'open') regimes - where transparency is the norm and access to resources and systems of government is relatively equal (Mungiu-Pippidi et al., 2011; Rothstein, 2011; Persson et al., 2013). The conditions under which nation-states move from a particularistic to a universalist society has been ascribed to a number factors - such as the development of universal education (Uslaner \& Rothstein, 2012) and the nature of democracy (MungiuPippidi, 2013).

While academics writing on corruption often position their work in either the principalagent or collective action camps, some have noted that the differences between principal-agent and collective action theories are not as stark as some scholarship suggests. Indeed, Peiffer and Marquette (2015) argue that recent scholarship has tended to overplay the differences between these theories, and that combating corruption ultimately requires drawing from both. For Peiffer and Marquette, it is the context in which corruption takes place that ultimately determines which lens it can be viewed through and how it might be addressed.

\section{The scale and context of collective action in the literature}

While the corruption literature often focuses on the national scale, scholarship on both collective action and principal-agent theories highlight the place-specific nature of these theories. For instance, moving to the subnational scale reveals that, as a number of geographers have suggested (e.g. Harvey, 1987; Cox \& Mair, 1988 Miller, 1992; Barnes and Sheppard, 2002), the potential for collective action is shaped by a range of placespecific factors.

For Miller, place-specific social relations that construct collective identities "often prefigure collective action", and allow for a broader conception of rationality: "one that recognizes the process by which understandings are reached, communal bonds formed, and collective identities constructed" (Miller, 1992: 39; 24). In turn, Barnes and 
Sheppard's work challenges the framing of collective action problems as intractable and dependent upon large-scale social change that moves societies from a particularist to universal condition; they contend that "the inclusion of place [as a factor influencing shared decision making] makes collective action more plausible than rational choice theory would allow." They conclude that:

The places in which everyday life is constituted provide all the conditions necessary for denying the general validity of the assumptions that legitimize the free rider argument (Barnes \& Sheppard, 2002: 1)

Drawing on an analysis of social activism, Bosco (2001) finds that place-based collective rituals are key to sustaining cohesion and social proximity in the face of activists' physical distance. In Lyon's (2003)'s words, “the ability of groups [engaged in collective action] to be sustained depends on the ability to build up trust", which is notably easier at the local scale. In other words, the places - and the associated norms, cultures and relations tied to these places - play a critical role in the nature of collective action. In turn, the nature of collective action problems differ across space as social, political, environmental and historical factors change.

Though the bulk of the literature focuses on the impact of local effects on collective action, the importance of place-based factors has also been the topic of scholarship on principal-agent theory. For instance, Boggs and Rantisi (2003) note that local conventions and institutions can reduce principal-agent problems, through reducing costs of information. Likewise, Feiock (2007) suggests a spatial element to information availability:

Many situations generate only partial information that may be distributed asymmetrically and the structure of the situation may cause actors to view risk, uncertainty, information asymmetries, and the actions attributes of other participants differently (Feiock, 2007, p. 48)

In turn, he suggests that principal-agent theory: 
must systematically address how context matters in specific choice situations, and how it affects the calculus of individual or corporate actors (Feiock, 2007, p. 48).

The nature and applicability of principal-agent problems are thus subject to the "proximity effect", the notion that principals are more likely to keep local officials accountable because of the close proximity of social relations (Tommasi \& Weinschelbaum, 2007).

Place-specific approaches at subnational levels are particularly important given increased global efforts to decentralize decision making, which shifts the locus of power and the potential for corruption. Decentralisation ostensibly provides greater community involvement in decision making and encourages greater transparency (World Bank, 1999). This process is supposed to reduce the potential for corruption; however, some have found it can simply decentralize it, causing corruption to jump scale. In examining decentralised poverty alleviation schemes in Eastern India, Vernon et al. (2006) describe a collective action problem wherein "local-level corruption is well organized and fairly institutionalized, such that even honest officers come under social pressures or even threats from their peers to become part of the system of corruption" and distribute resources amongst patronage networks. They argue that this comes about because, when vertical accountabilities are weak, community based monitoring systems "can degenerate into corruption networks between community representatives, local elected officials and local government officers" (Vernon, et al. 2006: 1397). In other words, decentralization can entrench corruption as a collective action problem.

So, the collective action turn within the corruption literature often focuses on the potential for corruption at the scale of the nation-state. Looking below the national scale highlights that corruption is a problem that is connected to social space - it is the economics, culture and politics that play out at different scales that determine the nature of the problem and potential to frame corruption as both a collective action and principal-agent solution. In the following sections we examine the way these considerations shape corruption and its responses to it in Papua New Guinea. 


\section{The case of Papua New Guinea (PNG)}

PNG is a parliamentary democracy with a unicameral parliament. While the country has experienced many political crises it has maintained democratic rule since its independence from Australia in 1975. Like many developing countries, corruption is a key concern to both those within and outside of the country. At the national scale, in comparison to other countries, PNG is considered a highly corrupt country. It is ranked as 139 out of 168 countries, scoring 25 out of 100, on the 2016 Corruption Perceptions Index (Transparency International, 2017). It rates poorly on other indices that attempt to measure the perceived levels of corruption within countries (World Bank, 2014). There are serious questions about the ability of these national-scale indices to depict actual levels of corruption, yet they act as a good proxy for how outsiders perceive the problem of corruption.

There are reports of dysfunction throughout the country - in all levels of the public sector (Payani, 2000), and involving elements of the private sector and civil society. It has thus been easy to talk about the problem of corruption in PNG as, in the words of a past Prime Minister Mekere Morauta, "endemic, systemic and systematic" (Australian Conservation Foundation \& CELCoR, 2006, p. 23). These assessments paint PNG with a very broad brush, suggesting that corruption may be a classic strong rational choice version of a collective action problem, whereby its ubiquity means citizens find it difficult to resist its temptations (Persson et al., 2013). However, this underplays the importance of place-specific analysis in determining the nature of the problem, the potentiality for collective responses to corruption, and the potentials for principals to keep agents to account.

The way corruption is understood in PNG differs across the country and over time. In remote locations citizens have been found to express greater sympathy towards corruption (Walton, 2013). The type of interaction that citizens have with the state also plays a role in determining definitions of corruption - in places where the state is weak citizens tend to define corruption more broadly (Walton, 2015). Perspectives on corruption also differ depending upon scale: with perspectives of those attached to national institutions such as the Ombudsman Commission differing from citizens (Walton, 2012). These insights suggest that the potential for collective action for or 
against corruption is, as Peiffer and Marquette (2015) suggest, subject to the context in which it takes place.

\section{Corruption in Papua New Guinea}

The most famous form of collective action associated with corruption in PNG is wantokism. Wantok means 'same language' or 'one talk' and refers to a reciprocal relationship of favours between family and community (Woolford, 1976). Wantokism encourages strong intra-group trust and constitutes collective identities; in turn wantok obligations are often felt to be stronger than loyalty to the nation-state, meaning that individuals preference kith and kin rather than following state rules and laws. Thus wantok obligations are frequently associated with the perpetuation of corrupt practices such as nepotism and election related bribes (Dinnen, 1997), leading Crocombe to argue that the "cohesion of local societies is often strong, but not well geared into, and often in conflict with, government institutions" (Crocombe, 2001, p. 444).

Kanekane stresses that these formations differ by place and between social scales, noting that "Papua New Guineans value relationships, whether they are attachments to clan, wantok group, or region. Along with that comes an obligation to strengthen such relationships, either through formal processes or casual gestures" (2007, p. 25). Providing services and favours to family and community members is seen as a means to fulfill cultural obligations and can be condoned by segments of PNG society particularly by those who may benefit. Local level corruption is subsequently seen to have a functional role as a social protection mechanism, which problematizes suggestions that all types of "corruption" are morally wrong, and opposed by local communities - as some of the collective action literature suggests (Persson, Rothstein, \& Teorell, 2013).

The nature of collective action towards corruption is also shaped by the types and strength of traditional governance systems. Like other Melanesian societies (including PNG, some of East Timor, and Solomon Islands) clans are broadly organized around two types of governance systems: chieftain (hereditary leadership) or 'bigman' (generally a more meritorious) systems, and for many are the primary source of social protection 
and identity. It is the latter which has come to be most associated with political leadership in PNG, and the sustenance of patronage systems that enable corruption.

'Big-man' is a heuristic term for a model of leadership based, amongst other characteristics, on the "ability to accumulate and distribute resources" (Crocombe, 2001, p. 412). Resources distributed to constituencies and wantoks often take the form of government development funds and are utilised to gain 'big-man' status (Dinnen, 1997, p. 191). Kombako neatly summarises the influence of localised kinship distribution on PNG's modern state system:

When corruption permeates the State, political office becomes the most promising avenue for gaining access to resources for local 'redistribution'. Political leaders build prestige and following through the allocation of grants, development projects, infrastructure services, and other resources to their constituencies. State 'gifting' becomes a means for constituting political 'bigmanship' (Kombako, 2007, p. 24).

Blurring the boundaries between citizens and the state through patronage is thus characteristic of what has come to be known as 'bigman politics' - which is characterised by a highly personalized exercise of political power, as opposed to impersonalized power within idealized Weberian bureaucracies. As such, PNG closely resembles the particularist societies described by collective action theorists (MungiuPippidi et al., 2011; Rothstein, 2011; Persson et al., 2013) wherein access to government resources is frequently contingent on one's connections. Yet, it is important to note that the nature of these relationships have evolved throughout PNG in different ways: as numerous anthropologists have shown (Sahlins, 1963; Gregory, 1982; Brown, 1990; Ketan, 2004), 'bigman politics' plays out differently across the country; a point we elaborate upon later in this paper.

The PNG state, as a weak and fragmented as it is, has tried to counter both corruption and poor levels of service delivery. National efforts to counter corruption have mostly been focused on developing state-based institutions that reflect principal-agent responses to the problem - with national anti-corruption agencies and strategies focused on monitoring and sanctioning key agents (particularly state officials and politicians) rather than shaping citizens' norms and values and building trust (Jones, 
2015). They are also highly centralized, with most anti-corruption institutions based in the capital, Port Moresby, with little reach across the country. Approaches to improving service delivery, on the other hand, have - particularly in recent times -sought to devolve power down to more local levels of government. This is encapsulated by growing constituency funds and decentralization to the district level of government, as outlined below.

\section{Decentralised service delivery and corruption}

In an attempt to improve sub-national service delivery, in 2014 the PNG government passed the District Development Authority Act (State of Papua New Guinea, 2014), which establishes District Development Authorities (DDAs) as legal entities that can sue and be sued. The act formalizes and expands functions of districts, PNG's second lowest administrative unit (higher units are national and provincial; lower, Local Level Governments [LLGs]), and sets of rules on how district funds are spent. Similar to the less formalized institutional arrangements proceeding them (Papua New Guinea Department of Implementation and Rural Development, 2013), DDAs are overseen by a management board, which comprises of the MP for the district (or open electorate); heads of the LLGs in the district and three other members appointed by the Minister of Parliament (MP) (Department of Provincial and Local level Government Affairs, 2015). Each of the 89 districts essentially comprise boundaries for one electorate; in turn, one 'open electorate' MP is directly elected for each district every five years. Once elected the open MP represents his/her electorate in the national unicameral parliament along with 22 Governors, who represent each of the country's provinces. Table 1 outlines the official role of key personnel on the DDA. 
Table 1: Key Personnel on the DDA

\begin{tabular}{|l|l|}
\hline Name & Official Role \\
\hline Open MP (Chairperson) & $\begin{array}{l}\text { Chairs meetings; decides on dates of meetings; has } \\
\text { deliberative vote, and if votes equal, casting vote. }\end{array}$ \\
\hline $\begin{array}{l}\text { LLG Presidents } \\
\text { representatives (up to } \\
\text { three) }\end{array}$ & Votes on activities and spending of DDAs. \\
\hline $\begin{array}{l}\text { District Administrator } \\
\text { (CEO) }\end{array}$ & $\begin{array}{l}\text { Responsible for implementing decisions of the DDA; } \\
\text { supervision of DDA staff. }\end{array}$ \\
\hline
\end{tabular}

Adapted from: State of Papua New Guinea (2014).

A District Administrator acts as the Chief Executive Officer (CEO) of the DDA; it is the CEO's responsibility to implement decisions of the board. The act makes it clear that only the board can make final decisions on funds. Section 29 (2) states that "the Board must decide matters at a meeting by a majority of the votes of the members present at the meeting" (State of Papua New Guinea, 2014). The Act also stipulates that decision making processes involve the community, with all quarterly meetings to be open to the public.

The act sets out a principle-agent framework for monitoring agents. Under the new legislation the CEO is the agent to the board (including the MP). However, the CEO is not as autonomous as the legislation suggests, as the open MP has a significant say in appointing this position. Indeed, John Kali, the Secretary of Personnel Management has indicated that while the DDA makes a recommendation for appointment to the Provincial Administrator, the Provincial Administrator is required to consult with the open MP about who to appoint (Kali, 2016), making the CEO's position subject to adverse selection. In turn, research in another part of the country (Central province) 
revealed that for some: "The CEO will never say no to the MP. If he says no, he is at risk [of losing his job]" (Kanaparo, Lokinap, Davda, Wiltshire, \& Walton, 2016). In other words, the CEO often works as the MP's proxy, rather than a separate agent, and thus is subject to a form of adverse selection that is common in public services subject to clientalistic political pressure (You, 2015; Aspinal, 2016).

In turn, open MPs can be the most important agent in deciding how funds are spent, and their role as an agent for both the DDA board (who are supposed to make joint decisions on funding helping to ensure that the MP does not make decisions unilaterally) and voters (who are meant to be informed about, and observe, funding decisions and spending and can keep MPs accountable through five-yearly elections) is what we focus on in this paper.

DDA legislation comes at a time of significant increases to funding to the district level. The District Services Improvement Program (DSIP) introduced in 2007, is a renewed version of the Electoral Development Fund that has been running since the 1980s and gives MP's, alongside other prominent community members, direct control over state development funds (Howes, Mako, et al., 2014, p. 128). The DSIP is intended to fund projects in areas such as health, education, transport, water supply and sanitation, law and justice, and communication (Auditor-General's Office of Papua New Guinea, 2014). While the figures are contested, between 2007 and 2012, PNG's 89 open (district) MPs were given around 20 million kina (7.6 million US dollars) each in DSIP funding since they were elected in 2007. In the years leading up the establishment of DDAs, these funds significantly increased. In 2013, the funding for DSIP increased to 10 million kina (3.15 million USD) for each open MP just for that year (Howes, Mako, et al., 2014, p. 128). In the 2014-16 budgets, open MPs were allocated a further 10 million Kina each per year (Howes, Voigt-Graf, \& Flanagan, 2014; Flanagan, 2015) ${ }^{3}$.

While aimed at adressing poor rural service delivery, it is widely acknowledged that the DSIP is prone to patronage demands and has been poorly implemented and monitored

\footnotetext{
${ }^{3}$ An extra 5 million kina was allocated for health an education in the 2016 budget, although this was halved in a following supplementary budget (Flanagan, 2015); in personal interviews with one of the authors a number of provincial staff complained of not receiving these.
} 
(Wiltshire, 2013; Auditor-General's Office of Papua New Guinea, 2014). In the mid1990s political scientist Ben Reilly summed up the problem with what were, by that time, being referred to as 'slush funds':

The funds were originally envisaged as a useful initiative for utilising a sitting member's intimate knowledge of local needs to bypass bureaucratic bottlenecks and fund roads, bridges, and other basic infrastructure where they are most needed in an electorate, thus (presumably) increasing overall living standards and cohesion. Instead the provision of such direct funding has more often served to reinforce fractionalization at the electoral level, as funding is widely expected to be a 'payola' from the winning candidate to reward and reinforce clan support (Reilly 1996, p. 69 cited in Ketan, 2007, p. 8).

Civil society groups - led by the local chapter of Transparency International - protested increases to these funds in the mid-2000s, fearing that the money would be wasted due to corruption (Pelto, 2007). They were successful in temporarily halting the proposed increase these funds. The Auditor General's 2012/2013 review of the program found an array of problems in DSIP implementation including "a pervasive breakdown in the DSIP governance framework; and ineffective spending of DSIP grants including potential misuse of DSIP funds" (Auditor-General's Office of Papua New Guinea, 2014, p. 12). Many projects were either outside the intended scope of the DSIP or uncompleted, and there was a "high risk of fraud" in the management of projects (Auditor-General's Office of Papua New Guinea, 2014, pp. 12-13). The research outlined below focuses on the ways newly formed DDAs utilize these funds, and how decision making adheres or otherwise to DDA legislation.

\section{Methodology}

This article draws from research undertaken between May and June 2016, which examined how PNG government policies (including decentralization) had impacted service delivery. Qualitative methods (semi-structured interviews, participant observation and focus groups) were undertaken with provincial and district bureaucrats, as well as a number of stakeholders connected to primary schools and 
primary health facilities - including head teachers, teachers, members of governing committees, and health workers and managers.

Interviews were undertaken in two provinces - East New Britain (ENB) and Gulf provinces - which have, as discussed below, very different histories and capacities for service delivery. Provinces and districts were chosen purposively based on their performance on primary health and education indictors according to data from a previous study within these provinces (Howes, Mako, et al., 2014). In each of these provinces administrators were interviewed from two out of four districts in ENB (Pomio and Gazelle districts) and both districts in Gulf (Kikori and Kerema districts).

\section{Sites of research}

Gulf and ENB are provinces with very different histories of development. ENB (see image 1) is located on the eastern half of PNG's largest island. The province has, by PNG's standards, a relatively long engagement with modernity. The island received a visit from William Dampier in 1700, when it was labelled Nova Britannia or New Britain. In 1884 the Germans proclaimed a protectorate over the New Britain Archipelago, with plantations - particularly Copra and coconut (Connell, 1997) - quickly introduced. Bray (1985) has suggested that those in the province, particularly the Tolai and Duke of York Islanders in the North-East, had been given a head start on other Papua New Guineans given their early engagement with Westerners - for Bray this was evident by their higher levels of education. There is also some suggestion that the use of shell money before and during colonial times may have helped some in the province adapt to capitalism (Errington \& Gewertz, 1993). ENB was one of the first (along with North Solomons, now known as Bougainville) to have a fully elected provincial government post-national independence (in 1975). Despite these achievements and good fortune, the province has faced some significant challenges. Thousands of people were relocated from the then-capital Rabaul after a volcanic eruption in 1994, which caused the capital to shift to Kokopo. Relocation of those directly affected caused significant social disruption. Still, the presence of this active volcano has a silver lining: the surrounding land benefits from rich volcanic soils which boosts crop yields. Development is spatially differentiated within the province. While the southern district of Pomio - covering three-quarters of the province, it is ENB's largest and most remote district - suffers 
from poor transportation links, the northern most populated areas are well connected with good road networks and the best natural harbors of the South Pacific (Rannells \& Matatier, 2005).

\section{Image 1: Location of East New Britain Province}

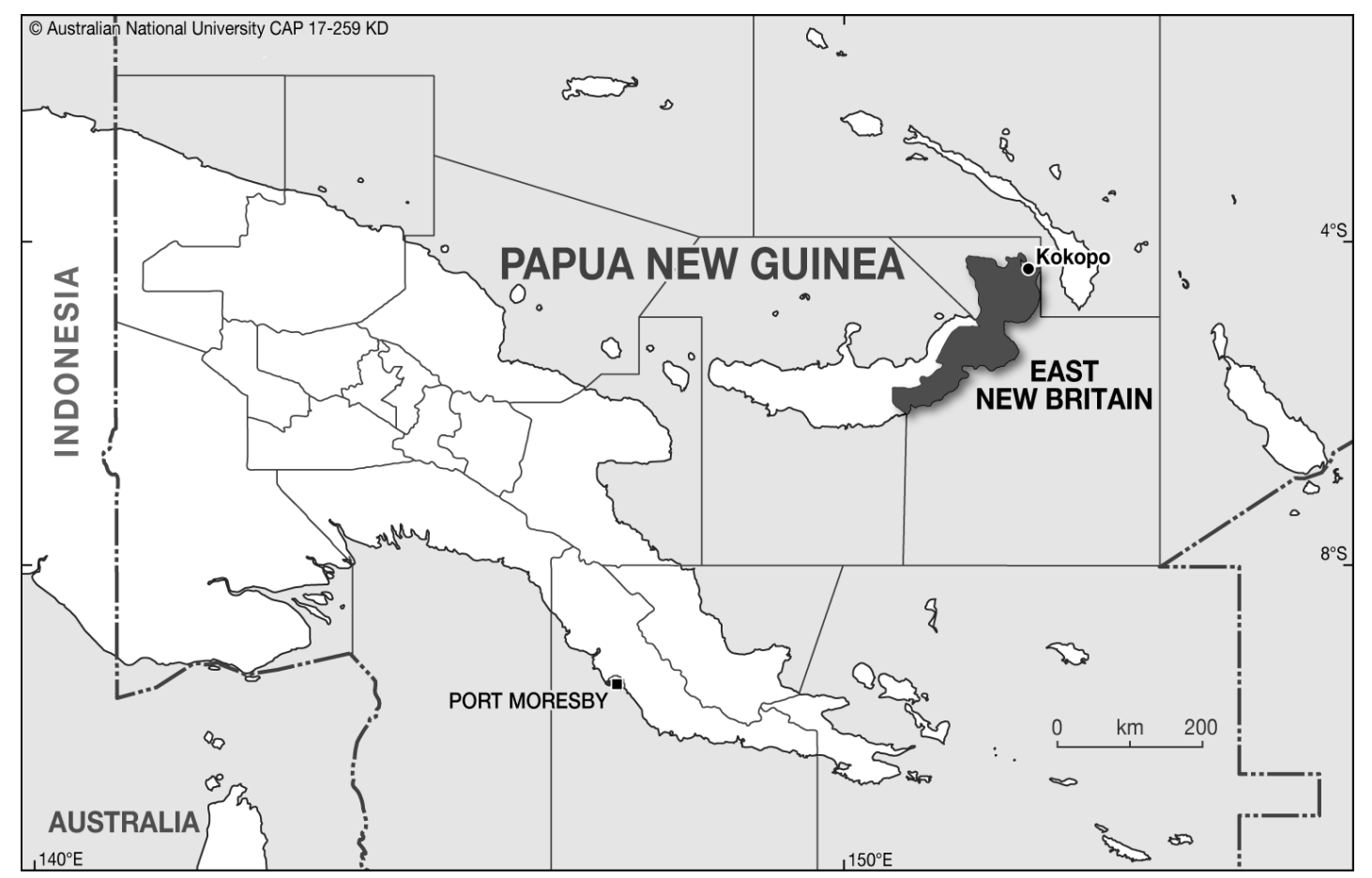

Source: Carto-GIS ANU, Kay Dancey

If ENB's history and geography has given the province a head-start, then Gulf province (see image 2), located in the south of PNG's 'mainland', has a significant handicap. In much of the province income opportunities are extremely limited because of the very poor land resources (Connell, 1997) and remoteness. The province has some of PNG's heaviest rainfall, and rivers and swamps hinder communication and transportation. Gulf's rich natural resources suggest a hidden potential, but thus far the exploitation of these resources has resulted in few tangible benefits. The province was the site of the first recorded discovery of oil (Connell, 1997), and today it is home to both oil and gas pipelines (both of which provide royalties for some landowners). The gas pipeline is part of PNG's large-scale LNG project, which connects fields in Western province to processing plants in the bay of Gulf and the capital Port Moresby. The initial stages of another LNG project, known as the Elk-Antelope gas field, is set to be based near the 
Purari River, in Gulf province, about 360 kilometers north-west of Port Moresby. Despite these projects the region is significantly underdeveloped.

\section{Image 2: Location of Gulf Province}

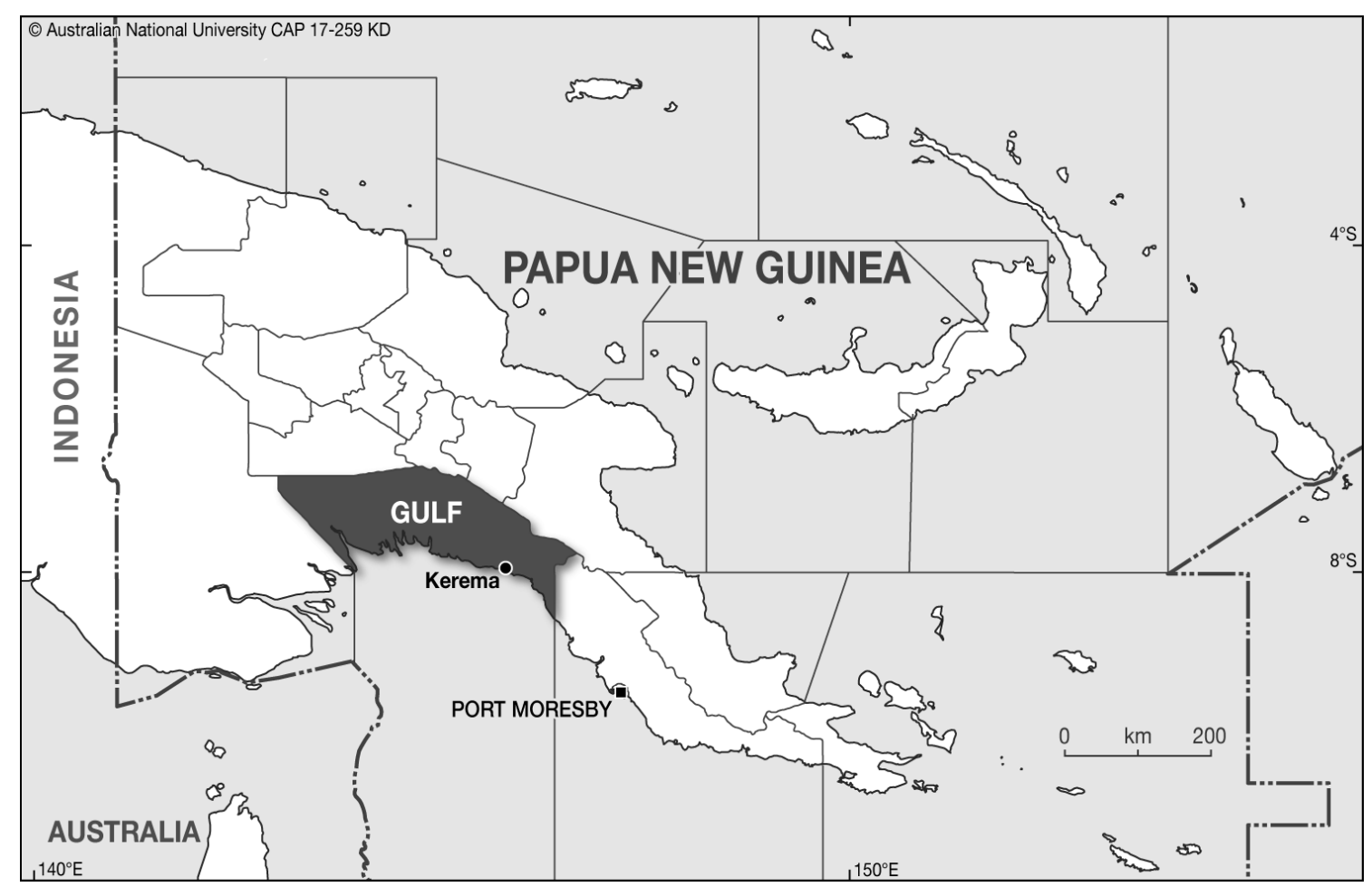

Source: Carto-GIS, ANU, Kay Dancey

The difference in development between ENB and Gulf is highlighted by recent research into changes in health and education service delivery in PNG (Howes, Mako, et al., 2014). Between 2002 and 2012 the proportion of parents of school children saying that most children in the community went to school rose from 37 to 90 per cent in ENB; in Gulf it fell from 63 to 37 percent (Howes, Mako, et al., 2014, p. ix). While the province still faces significant challenges, ENB stood out as the best performer out of the eight provinces included in the survey. Health facilities in the province conducted the most health patrols, and both schools and health facilities were better maintained and had a higher proportion of staff positions filled (Howes, Mako, et al., 2014, p. x). Gulf, on the other hand, was one of the worst performers for service delivery in both the primary education and health sectors. 


\section{Decentralization and the potential for corruption in Gulf and East New}

\section{Britain}

As previously highlighted, DDA legislation has ostensibly been designed to ensure powerful agents are kept to account. This section highlights the difficulties of this aim in the context of Gulf and ENB.

\section{Managing the DDA in Gulf Province}

As discussed, the DDA is made up of the open MP, three representatives appointed by the MP, and the LLG Presidents, who are elected by their constituents. As decisions are legally required to be made by a majority, the role of LLG presidents is particularly important. LLG presidents are ostensibly independent from the MP, and, because they can often outnumber the MP and his/her appointees, are pivotal in keeping the MP to account ${ }^{4}$. However, in Gulf those with an intimate understanding of the system, including an LLG President, were adamant that there was little LLG Presidents could do to keep MPs accountable or influence their decision making. One senior public official said: "LLG Presidents are [the MP's] puppets".

This marginalization had some of the hallmarks of a classic principal-agent problem, whereby the agents' control of information prevents principals from monitoring agents. Asked as to why the LLG Presidents, who represent their own constituents and are not appointed by the MP, don't just band together and collectively try to resist the MP, one LLG President said:

We could band together as LLG presidents and vote down the member but only if the DDA operates in the way it should... The member comes to the meeting to ask for approval and we (LLG presidents) have to give approval because half of the funding is already spent. If we were given the agenda before the meeting then we could talk amongst ourselves but we have no time to study the documents before us.

\footnotetext{
${ }^{4}$ This issue was brought to our attention by Colin Wiltshire, Australian National University.
} 
The MPs' control over information resulted in an inability of LLG Presidents to monitor this powerful agent. Respondents also confirmed that positions of influence - such as the CEO - were subject to adverse selection, with MPs having significant say over their activities. Likewise, citizens are unable to monitor these decisions as DDA meetings were often not advertised and were held in the national capital, Port Moresby, over 300 kilometers from the capital of Gulf province, Kerema. Most people from Gulf would not have the means to make this journey even if they knew about it. Without this information it is impossible to monitor MPs.

The absence of information is, however, the symptom of a much more widespread problem of patronage politics that has implicated MPs, communities and members of the bureaucracy. Those with an intimate knowledge of DDA often said that the whole institution was oriented towards implementing the MP's 'shopping list'. This shopping list focused on infrastructure projects close to communities who voted for the MP in the last election. As one senior district administrator, with long first-hand experience with district administration, noted: "The open [MPs] direct the money themselves - they spend it where they got their votes". An LLG President lamented that the only reason funding was provided to a community in his constituency was because they had vocally supported the incumbent MP. While this small community received funding for a health facility, the rest of his constituency missed out. From a collective action perspective, we see the particularistic distribution of DSIP funds (funds ostensibly decided on by the DDA) trumps all other considerations, and results in the procedural initiatives outlined in the DDA Act (2014) being difficult to enforce.

In Gulf there is an acceptance in some quarters that patronage politics is the way in which the redistribution of state resources should take place. Indeed, patronage politics often turn into a collective action problem that overrides attempts to institutionalize decision making through the state administration. This became apparent talking to one provincial administrator, in charge of key service delivery funding and decision making. Initially he decried the dysfunctional nature of the current DDAs in Gulf, but this did not stop him from wanting to head the DDA as an open MP. To do so he was cultivating relationships through his official position, in order to mount an election campaign in 2022. This meant building trust and goodwill among communities of potential future 
supporters; this - like in other developing countries (Aspinal, 2016) - means the bureaucracy is infused with patronage networks before public officials seek election.

When it came to dispersing the funds under his control, he made sure that communities thought he was personally providing funding. This would mean visiting communities that would benefit, and implying that he was providing the funds. He was not only targeting the adults with this display, he also had their children in mind; for him they were future voters in his upcoming campaign. He also facilitated payments to those in non-governmental organizations for training and per diems in a way which ensured they "owe him something" and would support his electoral run. This administrator was putting people in his debt to ensure they turned into loyal voters when the time came.

\section{Community responses to the vagaries of politicized funding in Gulf province}

As we've seen, funding decisions in the DDAs are driven by the MP, and can bypass communities who are not considered past or potential electoral supporters. One community visited fell into the latter category - they had not received funds from the DSIP, and most did not support the current MP. While many bemoaned this lack of support, a number acknowledged that they were a part of the 'big man politics' that contributed to this situation. In one male focus group, respondents suggested that bribery during elections was usually done in secret, only with people the candidate knew. Yet - suggesting that patronage and corruption was a collective action problem - they felt implicated in this process, as during elections it was the entire community who participated in the feasts paid for by candidates, knowing that they wanted their vote in return. When candidates came to their village, one participant said, "they give us money, we cook rice, we eat food, we eat this, we drink beer". Another said the MPs "provide everything" during these times of celebration. Anticipating the upcoming elections (scheduled for mid-2017), he continued, "now we are eating our own local food; we know the time for eating rice is coming". The point being that rice - a commodity bought at stores - would be paid for by candidates. They felt they were a part of a broader process of patronage that was inescapable as it was strongly tied to culture: "we have our culture tied to [gift giving between political leaders and the community] - it is our culture to give to our wantok," one said. 
As a result of such patronage politics, respondents had become cynical towards the development process. One said:

For the last 40 years, [development is]... what they've been preaching about, all candidates coming in here. "We'll bring in this. We'll bring in that." We're still waiting.

This resignation was said to play out during elections. Asked if there was any talk of issues impacting the community, such as health or education, during elections, respondents felt that they didn't say enough. One respondent simply replied, "I talk about what I'm supposed to get now [not later]".

These respondents, it could be argued, are caught up in what some collective action scholars call 'systemic corruption'. Some suggest that this results in citizens being more likely to support corruption (Persson et al., 2013), and the acceptance of gifts within the community suggests that during elections this is the case. Yet what makes this example interesting is the way this dysfunctional system (which might considered functional for those who receive largesse [see Walton, 2013]) has not resulted in simply a resignation that gives over to corruption norms, but in a collective determination to respond to a capricious administrative and political system.

This community decided to reestablish a community organization, which was to apply for funding, and try to navigate the various pathways to development. Their committee "was basically formed because...services were not coming down to us". They saw the committee as a way to apply for funding, and to reach donors and other funding agencies. This decision arose out of frustration with being outside of the strong patronage networks of other communities and elected MPs. Respondents complained about submitting a proposal to government agencies that were ignored because the bureaucracy was filled with people "appointed by politicians". They believed their proposals were not being looked at seriously because they did not support the incumbent MP. As one respondent said: "Most of us want a new member, so they will never look at your document". As outsiders to established patronage networks, they developed their own collective response to better engage the system. 
Their willingness to engage the system in a more collective manner was also influenced by place-specific considerations. The community was close to Port Moresby, and thus had greater access to alternative funding sources, such as donors and NGOs. There was also a cohort of respondents who were well educated, some who had worked for the national government. In other words, they had some understanding of how they might access other funding. The community had not received significant funding from the district or other government sources, yet there were signs of development around the community none-the-less. The school boasted a double classroom, teachers house and ablution blocks, provided by the Australian aid program. The Japanese aid program also funded the building of a double classroom. An access road to a nearby airstrip had been built by the resource extraction company InterOil to facilitate exploration in the area. There were remnants too of the church's development in the early years of the community's settlement in the 1950s, with a jetty and access roads built by missionaries. These structures were place-specific reminders that development could manifest if the right partners were engaged, and that the collective action problems of both communities and administration could be overcomes given the right types of actors. They helped to shape a collective trust that engaging with the system would result in development.

So the DDAs in Gulf are a far cry from intention of the DDA Act, which encourages a deliberative approach to decision making. This is because LLG Presidents and communities (two key principals) are actively marginalized, making them unable to keep MPs to account. In turn, the DDA's principal-agent framework is frustrated by ongoing processes which reward patronage; this can result in abuses of 'public office for personal gain' (a popular definition of corruption), both within the DDA itself and within other parts of the sub-national state administration. Still, communities can draw on their own place-specific contexts to reimagine the potential for types of development not tainted by these systems. 


\section{Managing the DDA in East New Britain}

In comparison to Gulf's lack of district planning, districts in ENB had very clear plans and goals. The provincial administration and districts have nine strategic results areas (SRAs) ${ }^{5}$ which guide the allocation of available funds, particularly DSIP funds. Those involved in administering and applying for funds by and large understand these priorities. Districts have well-researched and thick district development plans that provide a list of priorities for the district, in line with these SRAs. One district even had desk calendars made up which listed key priorities for the district and the dates that DDA meetings were supposed to be held 6 . DDA meetings were reportedly held across the districts, even in more remote locations according to DDA board members. While the minutes of DDA meetings seemed non-existent in Gulf, in ENB copies were more easily obtainable. In one district, an LLG president said that while the open member sometimes dominates decision making, decisions are mostly made by a majority. Thus, in this environment information about DDA meetings, decisions and funding were more readily available suggesting that both communities and DDA members (both principals) were better able to monitor the MPs (agents). Adverse selection appeared to be less of a concern, with respondents highlighting the relative independence of decisions around the appointment of bureaucrats, including CEOs.

There was also evidence of more equitable distribution of resources and thus a relative absence of bigman politics, with one district drawing on district funding to equitably fund schools on a per pupil subsidy based on the number of enrolments. (Although a number of respondents were suspicious of the timing of these payments, coming as they did a year before the general election). There was also evidence that

\footnotetext{
${ }^{5}$ Nine strategic result areas: 1. Governance; 2 Health; 3 Economics (includes agriculture, forestry, fisheries); 4 Education (primary schools, assisting with elementary and high schools); 5 Community Development (Law and Order; Welfare; Churches; NGOs); 6. Infrastructure (roads and buildings); 7 Lands (we have a program under land mobilization talking about state leases and an integrated land group that looks at customary land ownership); $8 \mathrm{HIV} /$ AIDS (it is now a development issue not a health issue); 9 Disasters (natural and man made).

${ }^{6}$ Some these statements are aspirational in nature (when researchers visited some scheduled DDA meetings had not taken place); however, there was evidence of progress with a north-south road opened in May 2016; such documents also provided an important statement of intent.
} 
the district was making decisions based on community priorities, which were encapsulated by five-year planning documents available in district offices.

For a number of respondents ENB was better able to keep agents to account because of the relative separation of politics and administration. A senior advisor on service delivery said that while the bureaucracy was increasingly politicized - as it was across the rest of the country - ENB was not as bad as other provinces, with MPs by and large allocating funds according to the bottom-up (community developed) five year plans, rather than personal priorities. Like other respondents he put this down to ENB's cultural dynamics. "It's not like in [the north-eastern region of] Sepik," where he originated, he said. He believed people in ENB were more prone to respecting their leadership and taking the lead in experimenting with service delivery than in other parts of the country.

This is not to say that the province did not have problems with corruption. Indeed, the open MP of Pomio, Paul Teinsten, was one of the first scalps of the country's short-lived but successful anti-corruption organisation, Investigation Taskforce Sweep. Tiensten was convicted of corruption in 2014 and 2015, and is now serving a combined 12-year sentence. The arrest highlighted local commitment to the separation of politics and administration. Many said they were concerned about the MP's behavior at the time and that he deserved his sentence. Media reporting of the arrest also suggested that people in ENB were unsympathetic to his plight given his actions and links to corruption in the forestry sector (Dateline Pacific, 2014). Thus in ENB, this culture of accountability helps ensure due process in line with the broader aims of the DDA Act and in line with principal-agent theory. However, moving beyond the district to the community level reveals that the forces of collective action still shape the effectiveness of district funding and service delivery.

\section{Community responses to politicized funding in East New Britain}

Moving from the administration to the community level reveals that collective action problems still manifest in ENB. In one remote corner of the province, the use of district funds to influence communities has been less than subtle, and involved a more active and united involvement of community members. Community members recalled 
how they obtained a boat from their open MP. They invited him to give a speech at a local celebration. At the end of his oration the MP was presented with a proposal to fund a 25,000 kina (8,000 USD) dinghy to help them cross the gulf dividing them from the district capital. In front of numerous community members the MP said that he'd find the funding. And sure enough the village was given a new boat. This process confirmed by community members in a focus group and separately by a district administrator - was a transgression of the DDA Act, which calls for decisions around funding allocations to be made by the Board.

Communal pressures were also brought to bear on reporting corruption and other issues, which resulted in different types of collective response. An education inspector, based at the district administration, noted that he did not hear allegations of corruption from the communities - although he knew that it was going on. He suggested that this was because they were all connected through the wantok system, and thus less likely to report corruption. In other words, he suggested communities were collectively colluding to not report corruption. Wantokism also impacted on the reporting of infrastructure. He said that school inspectors and other officials were less likely to report poor infrastructure that required fixing if the officials were not related to the surrounding community. On the other hand, due to intra-group connections and trust, state officials connected to communities were more likely to overstate the deficiencies of local infrastructure, and thus ensure that their infrastructure in their wantok's community was maintained.

Again, these examples point to the ways that place-specific factors shape collective action, and the potential for and responses to corruption. The community's request for a boat was enabled by its location: it is relatively close to the district office, making it easier for the MP to visit, compared to many other communities. The connection that inspectors had to specific communities shaped the maintenance of infrastructure, and wantok relations could help hide corruption. Place-specific themes shaped collective responses, even though these responses occurred within a context more conducive to principal-agent solutions (i.e. conditions that allow for the monitoring of principals by various agents). 


\section{Conclusion}

When comparatively examining the potential for corruption involving politicians, administrators and communities below the nation-state, as we have done in this article, it is evident that the relevance of collective action and principal-agent theories are significantly shaped by context. Places where cultural and social values do not align to administrative rules (such as Gulf), and are dysfunctional, are more easily overtaken by collective action problems through adverse selection and patronage politics, at multiple scales. This does not, however, axiomatically lead to disenfranchisement and the willingness to engage in corruption by those most affected - as some of the collective action literature suggests (Persson, et al. 2013). Indeed, the case of the community visited in Gulf province suggests that embedded within collective action problems is the potential for collective action solutions; solutions which aim to better engage with actors not tainted by the existing system. The nature of these responses is shaped by political, administrative, cultural and social factors, tied to specific places. There is a danger in focusing on the nation-scale as much of the literature on corruption does, as doing so has the potential to overlook the localized responses within ostensibly systematically corrupt societies. In the case of places like Gulf, it can erase the willingness of communities to seek out alternative development pathways.

In places where there is an alignment between cultural and social values and administrative rules, principal-agent framings of potential corruption problems are more likely to be relevant (as they were in ENB). Even when the systems that are designed to address principal-agent problems are, by and large, working, there are slippages that shape collective responses. In ENB principals are more enfranchised and, given that the state system functions better, more able to keep agents to account. However, even here, place-specific factors shape the opportunity for and responses to corruption. At the community level corruption - or at least the potential for corruption was enabled by collective action, which provided solutions to communal development needs.

According to some of the collective action literature, to address corruption a shift from particularlist to universal societies is needed. Our case study suggests that the potential for communities to make this shift is dependent upon the context actors find 
themselves. This context varies both across and within societal and institutional scales. Looking for solutions to corruption thus requires a critical engagement with these concepts, particularly in places where the state is least able to keep agents accountable.

For policy makers these findings suggest that anti-corruption policies must be attuned to the places where interests are formed and centres of administration operate. In this case, it suggests that in places such as Gulf, policy makers should look to strengthen inter-community linkages. This could include building roads, improving communications networks, and supporting local grassroots movements and community groups willing to drive collective solutions. In other words, fostering a sense of nationalism or regionalism that could help break down the bonds of patronage. These types of activities are not generally considered to be traditional anti-corruption strategies, but given the collective action problems Gulf - and places like it - face, they are an important part of seeking long-term solutions to these problems. On the other hand, ENB suggests principal-agent inspired solutions such as improving information to agents, improving mechanisms for monitoring, and addressing adverse selection would more likely help improve governance. At the same time, attention needs to be given to also building inter-community trust between groups that have been marginalized from administrative centres of power.

\section{Acknowledgements}

This research was funded by the Australian aid program. We thank the following individuals for their involvement: Denise Lokinap, Peter Kanaparo, Tatia Currie, Tara Davda, and Colin Wiltshire. We thank Michael Cookson and Husnia Hushang for managing funding and logistical support. Thanks also for comments from Caryn Peiffer, Roger Bolton, Jong-Sung You, Bo Rothstein and Yoonkyung Lee on an earlier version of this paper. Thanks to Ashlee Betteridge for editing. 


\section{References}

Aspinal, E 2016, 'The Corruption Morass in Indonesia: Adverse Selection, Electoral Clientelism and Bureaucratic Corruption', paper presented at the American Political Science Association Annual Meeting, Philadelphia.

Auditor-General's Office of Papua New Guinea, 2014, District Services Improvement Program, Auditor-General's Office of Papua New Guinea, Port Moresby.

Australian Conservation Foundation, \& CELCoR, 2006, Bulldozing Progress: Human Rights Abuses and Corruption in Papua New Guinea's Large Scale Logging Industry, Australian Conservation Foundation and CELCoR, Port Moresby and Melbourne.

Barnes, T \& Sheppard, E 1992, 'Is There a Place for the Rational Actor? A Geographical Critique of the Rational Choice Paradigm*', Economic Geography, vol. 68, no. 1, pp. 1-21.

Barr, A, Packard, T \& Serra, D 2012, Participatory Accountability and Collective Action: Evidence from Field Experiments in Albanian Schools, The World Bank, Washington.

Boggs, JS \& Rantisi, NM 2003, 'The 'Relational Turn' in Economic Geography', Journal of Economic Geography, vol. 3, no. 2, pp. 109-116.

Bosco, FJ 2001, 'Place, Space, Networks, and the Sustainability of Collective Action: The Madres De Plaza De Mayo', Global Networks, vol. 1, no. 4, pp. 307-329.

Bray, M 1985, 'An Overview of Issues', in M Bray \& P Smith (eds.), Education and Social Stratification in Papua New Guinea, Longman Cheshire, Melbourne, pp. 1-30.

Brown, P 1990, 'Big Man, Past and Present: Model, Person, Hero, Legend', Ethnology, vol. 29, no. 2, pp. 97-115.

Bukovansky, M 2006, 'The Hollowness of Anti-Corruption Discourse', Review of International Political Economy, vol. 13, no. 2, pp. 181-209.

Connell, J 1997, Papua New Guinea: The Struggle for Development, Routledge, London and New York.

Cox, K \& Mair, A 1988, 'Locality and Community in the Politics of Local Economic Development', Annals of the Association of American Geographers, vol. 78, no. 2, pp. 307-325.

Crocombe, R 2001, The South Pacific (3rd ed.), University of the South Pacific, Suva.

Department of Provincial and Local level Government Affairs 2015, Guide to the District Development Authority. (January) Department of Provincial and Local level Government Affairs, State of Papua New Guinea.

Dateline Pacific. (2014). Is PNG's Government Committed to Tackling Corruption? Retrieved 24 April, 2017, from http://www.radionz.co.nz/international/programmes/datelinepacific/audio/25 93712/is-png's-government-committed-to-tackling-corruption

Dinnen, S 1997, Law, Order and the State in Papua New Guinea. State, Society and Governance in Melanesia, Australian National University, Canberra.

Errington, F \& Gewertz, D 1993, 'The Triumph of Capitalism in East New Britain? A Contemporary Papua New Guinean Rhetoric of Motives', Oceania, vol. 64, no. 1, pp. 1-17.

Feiock, R 2007, 'Rational Choice and Regional Governance', Journal of Urban Affairs, vol. 29 , no. 1 , pp. 47-63. 
Flanagan, P 2015, 'Expenditure in PNG's 2016 Budget - a Detailed Analysis', Devpolicy Blog, blog post, viewed 3 August 2016, <http://devpolicy.org/expenditure-inpngs-2016-budget-a-detailed-analysis-20151202/>

Gregory, C. A. 1982. Gifts and Commodities. New York: Academic Press.

Harrison, E 2006, 'Unpacking the Anti-Corruption Agenda: Dilemmas for Anthropologists', Oxford Development Studies, vol. 34, no. 1, pp. 15-29.

Harvey, D 1987, 'Flexible Accumulation through Urbanization: Reflections on 'PostModernism' in the American City', Antipode, vol. 19, no. 3, pp. 260-286.

Howes, S, Mako, A, Swan, A, Walton, G, Webster, T \& Wiltshire, C 2014, A Lost Decade? Service Delivery and Reforms in Papua New Guinea 2002 - 2012. The National Research Institute and the Development Policy Centre, Australian National University, Canberra.

Howes, S, Voigt-Graf, C \& Flanagan, P 2014, The 2015 Papua New Guinea Budget: The End of the Expenditure Boom. The Development Policy Centre, Canberra, viewed 1 August 2016, <http://devpolicy.org/the-2015-png-budget-the-end-of-theexpenditure-boom-20141119-2/>

Johnsøn, J, Taxell, N \& Zaum, D 2012, Mapping Evidence Gaps in Anti-Corruption. Assessing the State of Operationally Relevant Evidence in Donors' Actions and Approaches to Reducing Corruption, U4 Issues Paper No. 7, U4, Chr. Michelsen Institute, Bergen.

Jones, A 2015, 'Missing in Action: The Diminished Role of Collective Action in Responses to Corruption in PNG', Honours, The Australian National University, Canberra.

Kali, JM 2016, State of the Public Sector, Sound Recording, Development Policy Centre, Canberra, viewed 12 January 2017, <https://soundcloud.com/devpolicy/stateof-the-png-public-sector-mr-john-mao-kali>

Kanaparo, P, Lokinap, D, Davda, T, Wiltshire, C \& Walton, GW 2016, Creeping ReCentralisation in PNG's Education Sector, The Development Policy Centre, Canberra, viewed 17 October 2016, <http://devpolicy.org/creeping-recentralisation-pngs-education-sector-20160615/>

Kanekane, J 2007, 'Tolerance and Corruption in Contemporary Papua New Guine', in A Ayius \& RJ May (eds.), Corruption in Papua New Guinea: Towards and Understanding of Issues, The National Research Institute, Port Moresby, pp. 2326.

Ketan, J 2004, The Name Must Not Go Down: Political Competition and State-Society Relations in Mount Hagen Papua New Guinea, Institute of Pacific Studies, University of the South Pacific, Suva.

Ketan, J 2007, The Use and Abuse of Electoral Development Funds and Their Impact on Electoral Politics and Governance in Papua New Guinea, CDI Policy Papers on Political Governance (2007/02), Centre for Democratic Institutions, Port Moresby.

Kombako, D 2007, 'Corruption as a Consequence of Cultural and Social Idiosyncrasies in a Developing Society', in A Ayius \& RJ May (eds.), Corruption in Papua New Guinea: Towards an Understanding of Issues, National Research Institute, Port Moresby, pp. 27-38.

Lyon, F 2003, 'Community Groups and Livelihoods in Remote Rural Areas of Ghana: How Small-Scale Farmers Sustain Collective Action', Community Development Journal, vol. 38, no. 4, pp. 323-331.

Miller, B 1992, 'Collective Action and Rational Choice: Place, Community, and the Limits to Individual Self-Interest', Economic Geography, vol. 68, no. 1, pp. 22-42. 
Miller, G 2005, 'The Political Evolution of Principal-Agent Models', Annual Review of Political Science, vol. 8, pp. 203-225.

Mungiu-Pippidi, A 2013, 'Controlling Corruption through Collective Action', Journal of Democracy, vol. 24, no. 1, pp. 101-115.

Mungiu-Pippidi, A, Loncaric, M, Vaz Mundo, B, Braga, ACS, Weinhardt, M, Solares, AP, Skardziute, A, Martini, M, Agbele, F, Jensen, MF, von Soest, C \& Gabedava, M 2011, Chasing Moby Dick across Every Sea and Ocean? Contextual Choices in Fighting Corruption Berlin, Hertie School of Governance, Norad, Berlin.

Olson, M 1965, The Logic of Collective Action: Public Goods and the Theory of Groups, Harvard University Press, Cambridge.

Ostrom, E 1998, 'A Behavioural Approach to the Rational Choice Theory of Collective Action: Presidential Address, American Political Science Association, 1997', American Political Science Review, vol. 92, no. 1, pp.1-22.

Ostrom, E 2007, 'Collective Action Theory', in C Boix \& S Stokes (eds.), The Oxford Handbook of Comparative Politics, Oxford University Press, Oxford, pp. 186-208.

Papua New Guinea Department of Implementation and Rural Development 2013, PSIP, DSIP and LLGSIP Administrative Guidelines, Independent State of Papua New Guinea, Port Moresby.

Payani, HH 2000, 'Selected Problems in the Papua New Guinean Public Service', Asian Journal of Public Administration, vol. 22, no. 2, pp. 135-160.

Peiffer, C \& Alvarez, L 2014, Who Will Be the 'Principald Principals'? The Determinants of Active Opposition to Corruption, Research Paper (31), Developmental Leadership Program, Birmingham.

Peiffer, C \& Marquette, H 2015, Corruption and Collective Action, (Research Paper 32) Developmental Leadership Program, University of Birmingham and the U4 AntiCorruption Resource Centre, Birmingham.

Pelto, M 2007, 'Civil Society and the National Integrity System in Papua New Guinea', Pacific Economic Bulletin, vol. 22, no. 1, pp. 54-69.

Persson, A, Rothstein, B \& Teorell, J 2013, 'Why Anticorruption Reforms Fail-Systemic Corruption as a Collective Action Problem', Governance, vol. 26, no. 3, pp. 449479.

Rannells, J \& Matatier, E 2005, PNG Fact Book: A One-Volume Encyclopedia of Papua New Guinea (3rd ed.), Oxford University Press, South Melbourne.

Rothstein, B 2011, 'Anti-Corruption: The Indirect 'Big Bang' Approach', Review of International Political Economy, vol. 18, no. 2, pp. 228-250.

Sahlins, M 1963, 'Poor Man, Rich Man, Big Man, Chief; Political Types in Melanesia and Polynesia', Comparative Studies in Society and History, vol. 5, no. 3, pp. 285-303.

Sööt, ML \& Rootalu, K 2012, 'Institutional Trust and Opinions of Corruption', Public Administration and Development, vol. 32, no. 1, pp. 82-95.

State of Papua New Guinea (2014) District Development Authority Act 2014 (PNG), Resolution 40, (Certified: 22 December, 2014), , Port Moresby.

Tommasi, M \& Weinschelbaum, G 2007, 'Centralization Vs Decentralization: A PrincipalAgent Analysis', Journal of Public Economic Theory, vol. 9, no. 2, pp. 369-389.

Transparency International 2017, Corruption Perceptions Index 2016, Transparency International, International Secretariat, Berlin.

Ugur, M \& Dasgupta, N 2011, Evidence on the Economic Growth Impacts of Corruption in Low-Income Countries and Beyond: A Systematic Review, EPPI-Centre, Social Science Research Unit, Institute of Education, University of London, London. 
Uslaner, EM \& Rothstein, B 2012, Mass Education, State-Building and Equality: Searching for the Roots of Corruption, Vol. 5. University of Gothenburg: Quality of Government Institute, Sweden.

Vernon, R, Williams, G, Corbridge, S \& Srivastava, M 2006, 'Decentralized Corruption or Corrupt Decentralization? Community Monitoring of Poverty Alleviation Schemes in Eastern India', World Development, vol. 34, no. 11, pp. 1922-1941.

Walton, GW 2012, 'Comparing Local and International Perspectives on Corruption in Papua New Guinea', PhD, The University of Melbourne, Melbourne.

Walton, GW 2013, 'Is All Corruption Dysfunctional? Perceptions of Corruption and Its Consequences in Papua New Guinea', Public Administration and Development, vol. 33, no. 3, pp. 175-190.

Walton, GW, 2015, 'Defining Corruption Where the State Is Weak: The Case of Papua New Guinea', Journal of Development Studies, vol. 51, no. 1, pp. 15-31.

Wiltshire, C 2013, Reflections on the PNG Budget Forum: Can Devolved Funding Be Effectively Utilized?, Development Policy Centre, viewed 1 February 2016, $<$ http://devpolicy.org/reflections-on-the-png-budget-forum-can-devolvedfunding-be-effectively-utilised-2013040/>

Woolford, D 1976, Papua New Guinea: Initiation and Independence, University of Queensland Press, Brisbane.

World Bank 2014, World Wide Governance Indicators, viewed 12 May 2015, <http://info.worldbank.org/governance/wgi/index.aspx\#home>

World Bank 1999, Beyond the Center. Decentralizing the State, World Bank, Washington. You, JS 2015, Democracy, Inequality and Corruption. Korea, Taiwan and the Philippines Compared, Cambridge University Press, Cambridge. 